\title{
安定器内蔵形水銀ランプの高勃率化
}

\author{
専門会員 下垣光太郎* 正会員 越智 雅文* 柵木 教一*

\section{High Efficacy Self-ballasted Mercury Lamps and their Operating Circuits}

\author{
Kōtaro Shimogaki (Fellow Member) Masahumi Ochi (Member) \\ and Kyouichi Maseki
}

(R \& D Division, Iwasaki Electric Co., LTD.)

\begin{abstract}
The self-ballasted mercury lamps are now being widely used for the convenience to replace an incandescent lamp without using external ballast.

However, their lamp efficacy is relatively low for the reason that more than half of the lamp power is consumed in the ballast filament inside the lamp.

Moreover, the lamp used on the $100 \mathrm{~V} \mathrm{AC}$ line requires the hot cathode filament in its arc tube for the initiation of the lamp.

It seems that DC operation could improve the lamp efficacy by reducing the filament loss, however, other difficulties might arise, especially on the maintenance of the lamp and its operating circuit.

In this paper, the authors present the lamp and its new operating circuit to solve the problems.

The newly designed lamp with its oparating circuit doubles the lamp efficacy of the current self-ballasted mercury lamps, and yet requires no hot cathode arc tube.

At least 20,000 hours are expected as for the circuit life.
\end{abstract}

\section{1. は じめに}

安定器内蔵形水銀ランプは, 高压水銀ランブの発光管と直列に 白熱フィラメントを接繶して電流を制限するとともに，水銀ラン プの光と白熱電球の光を混合したランプである. したがって, 一 般の放奄ランプのように安定器を必要とせず, 簡便に白熱電球と 交換することができるので広く使用されている．寿命は主に白熱 フィラメントの寿命設定により決まるため, 効率の高いフィラィ ントを使用すると短くなるが，效率の低いフィラメントを用いる と，10,000時間以上の長寿命を得ることもできる. 効率は低効摔 の白熱フィラメントが約半分の電力を消費するため, 水銀ランプ より低くなり, 特に低容量の安定器内蔵形水銀ランプでは立ち消 え特性のために, 発光管電圧を相刘的に低くする必要があり, ラ ンプ効率は，1,000 時間寿命の白熱電球より低くなるといら結果 となる.

これらの欠点を克服するため若干の実験を行ない, 效率を約 2 倍に改善する見通しがついたので報告する.

$*$ 岩崎䉓気的開発部

\section{2. 現安定器内蔵形水銀ランプ}

\section{1 点灯回路と始動方式}

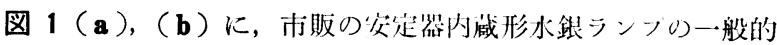
な点灯回路1)を示す。電源電生が $200 \mathrm{~V}$ 以上の場合には困(a)の回 路となるが，電源電生が $100 \mathrm{~V}$ クラスたなと始動に姴する䉓压

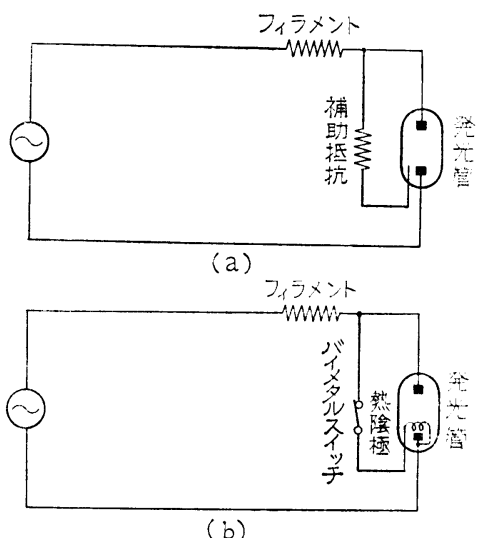

图 1 安定器内藏形水銀ランプの 点灯回路 
が不足するため，図(b)のようにコイル状フィラメントによる熱陰 極を用いて始動を容易にしている. しかしこの方式ではランプの 製造や,バイメタルスイッチの信頼性のうえで注意が必要であっ た.

\section{2 効 率}

安定器内蔵形水銀ランプの効率を決定する要因を分析する.

今, ランプ電力が $W_{l}$ のランプを考光, 発光管特よびフィラメ ントへの電力配分がそれぞれ $W_{b}, W_{f}$ であるとする。

すなわち,

$$
\begin{aligned}
W_{l} & =W_{b}+W_{f} \\
\text { ここで, } & \\
W_{b} & =V_{b} \cdot I_{l} \cdot P_{f l} \\
W_{f} & =V_{f} \cdot I_{l} \ldots \ldots
\end{aligned}
$$

ただし， $V_{b}$ は発光管電圧， $V_{f}$ はフィデメント電压， $I_{l}$ はラン プ電流, $P_{f l}$ は発光管の力率を示す.

一方，発光管招よびフィラメントの発光効率をとれぞれ， $\eta_{b}$ 特 よび $\eta_{f}$ と括けば, ランプ效率 $\eta_{l}$ は

$$
\eta_{l}=\left(W_{b} \cdot \eta_{b}+W_{f} \cdot \eta_{f}\right) / W_{l}
$$

となるが, ランプ電力に対する発光管電力の比, $W_{b} / W_{l}$ (以後, 発光管電力此々呼ぶ) を $K(0<K<1)$ とすれば,

$$
\eta_{l}=K \cdot\left(\eta_{b}-\eta_{f}\right)+\eta_{f}
$$

と表わすことができる. $\eta_{b}$ は斿よりも大きいから列は $K$ が大 きいほど大きくなる。

一方，発光管電力比 $K は ，(2)$ 式拈よび(3)式を用いて

$$
K=W_{b} / W_{l}=\frac{1}{1+\left(\frac{V_{f}}{V_{b}}\right) \cdot\left(\frac{1}{P_{f l}}\right)}
$$

となるが，Kを大きくするためには $V_{f}$ に対して $V_{b}$ を大きくす る必要がある.

ところが， $V_{b}$ を大きくすると放電灯は立ち消えを起こしやす くなるという性質があるので $V_{b}$ 值には上限がある。

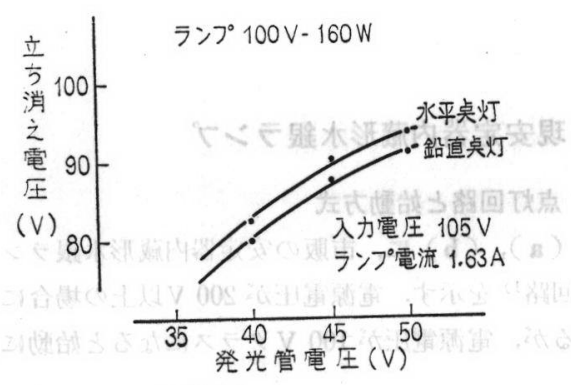

图 2 安定器内藏形水銀ランプの 立ち消え特性

図 2 に $100 \mathrm{~V}-160 \mathrm{~W}$ ランプの立ち消え特性の測定例を示す. 図から電源電圧変動が $10 \%$ あことを予想し, 点灯姿勢を考慮 し，さらに寿命中の $V_{b}$ の上昇を $3 \sim 5 \mathrm{~V}$ 見込むと $V_{b}$ の值とし て $42 \mathrm{~V}$ 程度となる.この值はランプ電圧の $1 / 2$ に及ばない。こ のよらに現状のランプでは, フィラメント電力 $W_{f}$ が発光管電力 $W_{b}$ を上まわる設計となる.このようなランプでは発光管の效 率が $30 \mathrm{~lm} / \mathrm{W}$ くらいであるのに詨し，フィラメントの効率は 長寿命とするため $6 \mathrm{~lm} / \mathrm{W}$ 程度にしかできないので，ランプ効率 は $13 \mathrm{~lm} / \mathrm{W}$ 程度の低効率になり，白熱ランプよりむしろ低いと いう結果となっている.

\section{3 ランプ効率改善への検討}

このランプの低効率の原因は, 上述のようにランプ電力 $W_{l}$ に

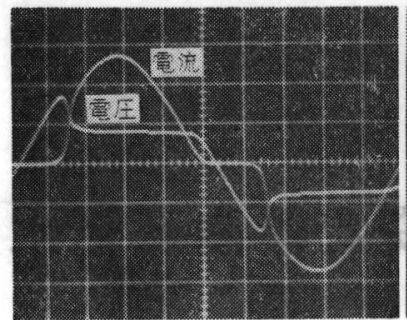

(a)

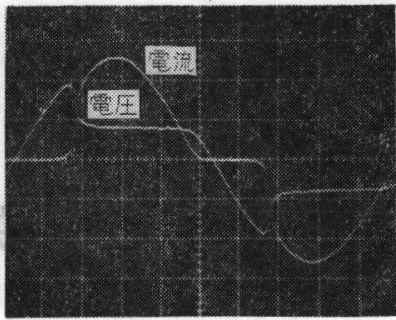

(b)
図 $3100 \mathrm{~V}-160 \mathrm{~W}$ 安定器内蔵ランプの発光管電圧の差に よる発光管電压 一電流波形 (繸: 電圧 $50 \mathrm{~V} / \mathrm{div}$, 電流 $1 \mathrm{~A} / \mathrm{div})$

$\begin{array}{ll}\text { (a) 発光管電纴 } 42 \mathrm{~V} & \text { (b) 発光管電圧 } 52 \mathrm{~V}\end{array}$

対して効率の高い発光管への入力 $W_{b}$ が小さく, 低効率のフィ マTMメントへの入力 $W_{f}$ が大きいことに起因している.

そこで効率を向上させるためには， $K\left(W_{b} / W_{l}\right)$ を大きくする かフィラメント効率を上げるかであるが, 後者の方法では寿命を 短くするわりには効果が少ない。前者の方法において問題になる のは放電灯の立ち消党である. 抵抗バラストで交流点灯するとき 発光管電圧が高いと, 図 3 のようにランプの電流休止期間が長 くなり, ランプ電圧と電光管電圧の ピーク值との差が 小さくな るので, 発光管電圧 $V_{b}$ をあまり高くできない，また蛍光体を外 球に塗付し効率を改善する方法 ${ }^{2}$ もあるが, その改善率は小さく 抜本的解決策にはならない. 大幅な効率改善を計るためには点灯 方式そのものを工夫して，V る必要がある.

今回, 発光管電力比を大きくする方法として直流点灯方式につ いて二, 三検討したので以下に述べる.

\section{3. 高効率点灯方式の検討}

\section{1 放電灯の直流点灯}

放電灯を十分に平滑化された直流電源にて点灯すれば，抵抗バ ラストに招いても，交流点灯時に見られるような再点弧による発 光管電圧のピークが生じない，それゆ発光管電圧を上げて発光 管電力比を大きくした高効率設計が可能となる.これに適する点 灯回路を見いだすために，筆者らは二，三の直流点灯回路につい て比較検討した.

\section{2 直流点灯回路の比較}

図 4 にダイオードブリッジ整流を用いた直流点灯回路の代表 例を示す. 図 4 (a) はブリッジ整流器の後にコンデンサを設け て平滑化してランプを点灯するもので最も一般的な方式である. この回路の無負荷出力電圧は入力電源電圧の $\sqrt{2}$ 倍となり, 水銀
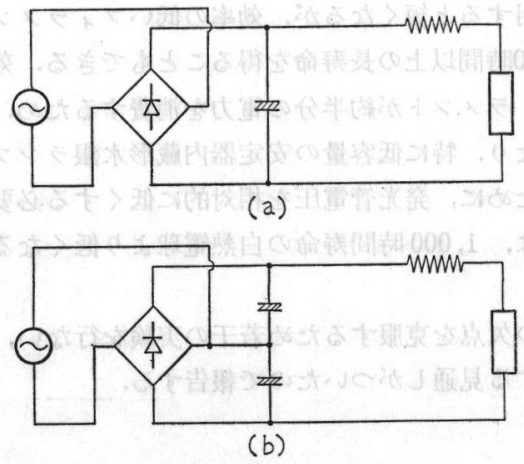

図 4 直流点灯回路の例 (a) 全波整流方式 (b) 倍電圧方式 
ランプを始動させる場合, 電源電圧が $200 \mathrm{~V}$ 以上の系統では十分 な值となるが，100 V クラスのときには不足する，一方，低い䉓 源電压に対応する方式として，図4（b)のような倍電压点灯方式 が発表されている3) 4).

この回路の無負荷出力電压は電源電圧の $2 \sqrt{2}$ 倍となるため, $100 \mathrm{~V}$ 程度の電源電压に扣いても, 始動のために十分な無負衡電 坐を供給できるといら利点がある、筆者らもこのう式で設計・試 験したところ始動に関しては長所が媤められたが，設計上注意す べき点もあることがわかったので以下に述べる。

図 5 （a），（b）は，倍電圧回路に抵抗を負荷したときの貝侕

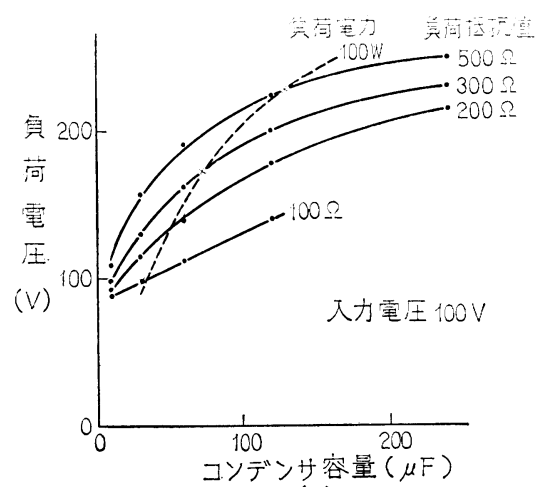

(a)

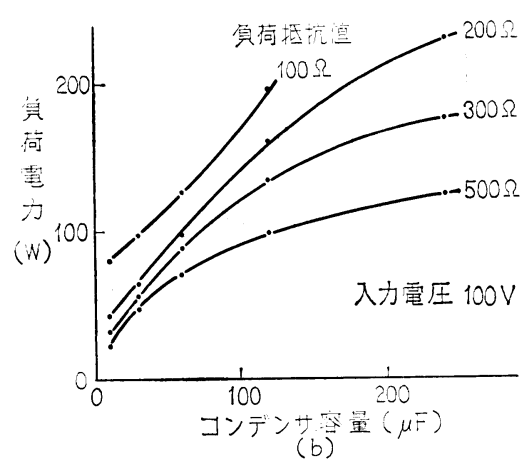

因 5 倍電生方式の纷荷電生 (a), (b)

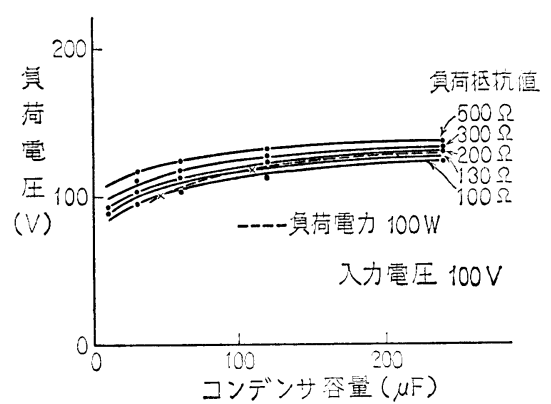

(a)

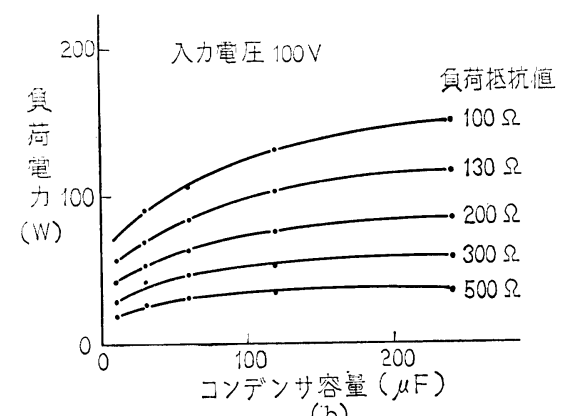

(b)

図 6 全波整流方式の負荷電圧 (a), (b)
軋压および負荷䉓力の特性であり, コンデンサの谷量值との関係 を測定したものである。

一方，図 6（a），（b）はこれに対応与る企波整流方式の場合 の特性である.これらの㲸から倍電生方式は全波整流方式に比較 して負荷の電圧，扣よび電力に対するコンデンサ容量值の影響が 大きいことがわかる.このことはコンデンサとして電解コンデン サを用いたときに問題となる.

まず，回路設計に颃いてはコンデンサの谷量ばらつきや，ライ フを通しての容量変化にも注意が必要である，次に容量値の選択 の問題がある. 図 $5($ a)のように负荷電力をある值に国定して考学 ると, 負荷電圧は容量値によって大幅に変化する。このことは発 光管電力比と定めたとき, 発光管電圧が決まれば容量傎が一議的 に決定されることを意味する．実用的な発光管電圧の範囲では, この容量值は負荷電力を同じにして比較すると, 全波整流力式に 㧍ける平滑コンデンサの容量值よりもかなり小さい值に選ばれる ことになる2゙，逆に全波整流方式の場合は，容量值が発光管電任 設定に与える影響がかなり小さいので，容量值をいくらでも大き くした設計が可能である．このことは電解コンデンサを使用する とき，その温度上昇に対して大きな差となって現われる。一般的 にいえることであるが, 電解コンデンサの許浴リップル電流值は 谷量値とともに大きくなる ${ }^{5 \sim 6)}$ 。すなわち，全波整流方式では容 量值を大きく選定することによりコンデンサの発熱の問題を軽減 できる.

電解コンデンサの発熱に関してもら一つの重要な問題は, リッ プル電流の周波数である. 電源の周波数が $50 \mathrm{~Hz}$ のとき全波整流 方式の場合, 平滑コンデンサに流孔る基本周波数は $100 \mathrm{~Hz}$ とな るが，倍電压整流方式の場合，一方のコンデンサに流れる電流の

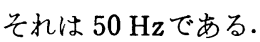

電解コンデンサの発熱の主要因は, 等価值列抵抗 (ESR) であ ると考兄られるが, ESR 值の周波数特性は $1 \mathrm{kHz}$ より下の範用 では周波数が下がる汪ど上昇する傾向にある.これは倍電圧回路 の場合コンデンサの発熱が大きくなり, 寿命の面でさらに不利に なることを意味する、これを確かめるために実際に雨者の点灯回 路を設計, 試作し、コンデンサの温度上昇を比較してみた. ラン

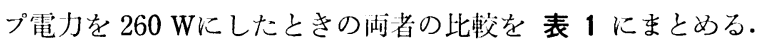

\begin{tabular}{|c|c|c|}
\hline 項 月 & 全 波 整 流 & 止 \\
\hline 入 力 電 压 & $100 \mathrm{~V}$ & $100 \mathrm{~V}$ \\
\hline ラン フ 電 力 & $260 \mathrm{~W}$ & $260 \mathrm{~W}$ \\
\hline $\begin{array}{c}\text { 使用した電解 （注）1 } \\
コ \text { ソデソサ }\end{array}$ & $220 \mu \mathrm{F} 160 \mathrm{WV}$ & $47 \mu \mathrm{F} / 47 \mu \mathrm{F} 160 \mathrm{WV}$ \\
\hline コンデソサ 電 流 值 & $3.1 \mathrm{~A}$ & $1.4 \mathrm{~A}$ \\
\hline |周 波 数 & $100 \mathrm{~Hz}$ & $50 \mathrm{~Hz}$ \\
\hline $\begin{array}{c}\text { コンデソサの } \\
\text { 温度上星値 }\end{array}$ & $35 \mathrm{deg}$ & $100 \mathrm{deg}$ \\
\hline コンデンサの寿命 & $\begin{array}{l}\text { 約 } 3,000 \text { 時間のライフテス } \\
\text { 卜实績有り }\end{array}$ & $\begin{array}{l}\text { 点灯後 } 2 \text { 時間程度で破壊す } \\
\text { 襄す }\end{array}$ \\
\hline
\end{tabular}

(注) 2. ランプ点灯後 1.5 時間経過したときの值.

この結果, 倍電压方式のコンデンサの盜度上昇値は異常に高 く，一般に市販されているグレードの電解コンデンサでは，ほと んど実用にならないことが判明した.

一方, 全波整流力式の平滑コンデンサの温度上昇値もやや大き いが，容量值設定やコンデンサのグレードを上げることで解決で きとうな程度のものである.しかしながら全波整流方式の場合, 電源電圧が $100 \mathrm{~V}$ のとき，始動に要する電圧が不足するといら 


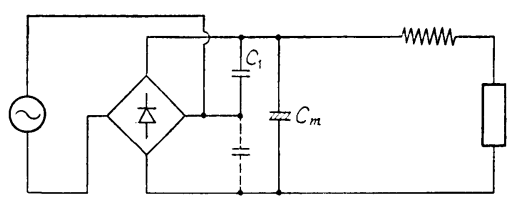

圂 7 变形した点灯回路

問题があっだ).

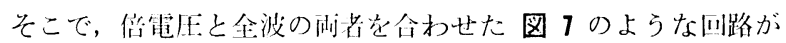
考えられる.この回路の $C_{1}$ に深量值の此䡆的小さい, 低損失 のコンデンサを用いることができるが，倍正作用が生じるので主 コンデンサ $C_{m}$ を倍電压に充電する. こうすれば始動時に十分な 電圧が得られると同時に, 点灯時は $C_{1}$ が小容量であるから回路 の负荷特性は, ほほ全波整流方式と同一となり, その長所を生か すことができる，しかし主コンデンサ $C_{m}$ の附電压を 2 倍にしな ければならないことのほか， $C_{1}$ の浴量值も西る程度大きくしな いと十分な電圧が得られないといら難点も生ずる.

\section{3 新しい直流点灯回路}

上述の問題点を解決するために考条した新点灯回路を図8 亿 示す.この回路の特徵はダイオードDを用いて倍生コンデンサ $C_{1}$ と主コンデンサ $C_{m}$ を分滩した点にある. 出力端の無负荷電圧波 形は図9のようになり，ピークとして倍電压がランプに印加さ れる. ダイオードDのため $C_{1}$ は大容量の $C_{m}$ を充電する必要が ないので小さくてもよく, 低損失のフィルムコンデンサなどが使 用できる. 实験の結果, $C_{1}$ の容量值としては, $1 \mu \mathrm{F}$ 程度でも始 動に対して十分であることを確認した. また $C_{m}$ に対しては通常 の全波整流方式の動作となるのでその长所を生かせる.

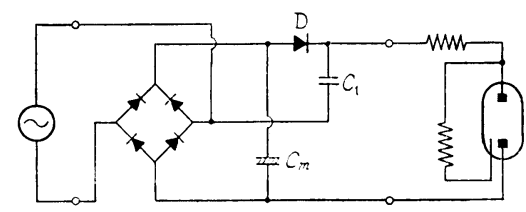

図 8 新点灯回路

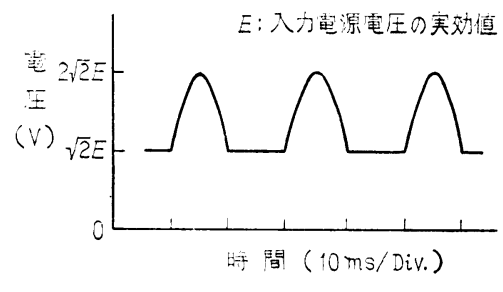

図 9 無们荷電目波形

\section{4. 高効率点灯回路の設計}

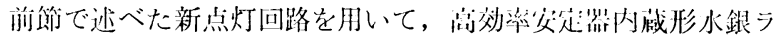
ンブの設計，試作を行なった．ランブ分格は $100 \mathrm{~V}-170 \mathrm{~W}$ 級い $100 \mathrm{~V}-250 \mathrm{~W}$ 級の 2 品種について述べる.

\section{1 ランプ効率の推定}

設計を始めるに当たり, 発光管の寸法和よび入力電力と発光効 率との関係を实験的に調べた。その結果得られたデータをもとに して安定器内蔵形ランプとしたときの, ランプ効率と発光管電力

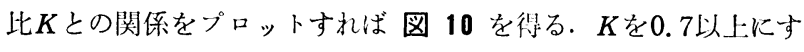
れば $30 \mathrm{~lm} / \mathrm{W}$ を越す效率が得られるが，Kを大きくしていくと やはり立ち消えの問題が生ずると思われ，立ち消兄特性を調查す る必要がある.

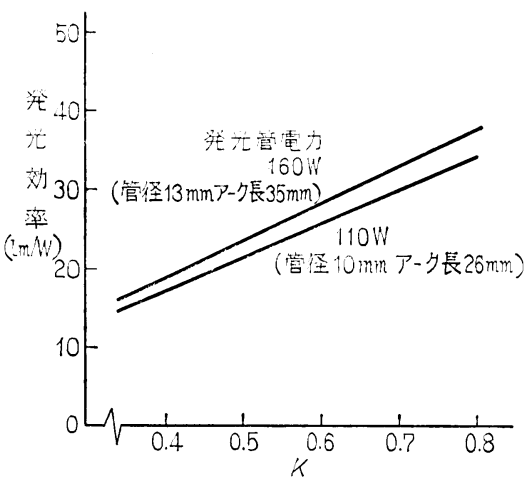

图 $10 K$ と発光効竬上の阔倸

\section{2 立ち消え特性}

全波整流直流点灯飞和外る放本ランフの立七消方特性は, 半滑 の度合い，すなわち平滑コンデンサの相対的大きさによって変化 することがわかった、コンデンサの谷量值を種々変えて測定した 立ち消光特性の例觉图 11 亿示す。

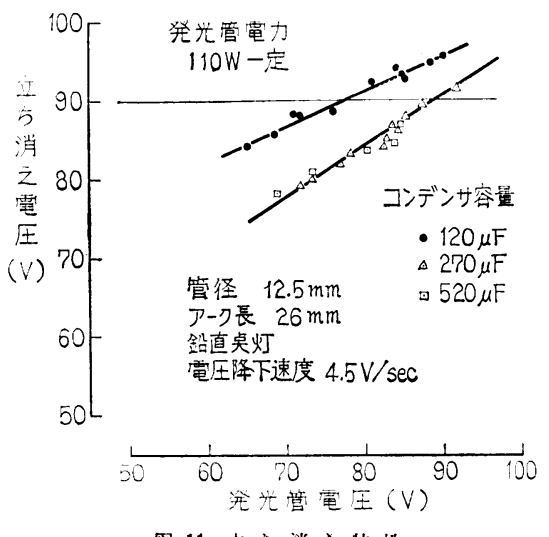

图 11 立占消关特珄

この例から谷量をある程度大きくすれば，立ち消兄特性が改善 できる。しかし央用的な設叶を行なら上では容量值とともに発光

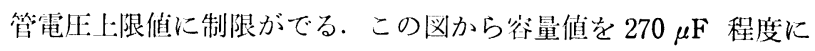
選んだ場合, $10 \%$ の電源電压降下を許谷するためには発光管電压 の上限值は $90 \mathrm{~V}$ 以下にしなければならないことがわかる.なお 今回の測定では，ランプ点灯姿勢による吉ち消光特性差は判然と は出なかった。

\section{3 電解コンデンサと回路設計}

平滑コンデンサは大容量となるので, 尖用的には電解コンデン サが選ばれる，電解コンデンサを仗用するに括いては，許行リッ プル電流や素子の洫度上昇,さらには夙国温度と寿命の関係な ぞ設計上留意すべき点がある.

まず, リップル電流の招上その大きさを知るために可変抵抗少 を負荷として，負荷電力とリップル電流との関係を調べた。この 結果を図 12 に示す. 貞荷電力が $250 \mathrm{~W}$ 程度になると,リップ ル電流は 3 Aを越えるようになる.一般市販品の中からこのよう な大きな電流許容值のものを選ぶとすると, 容量值を相当大きく しなければならない、さもないとコンデンサの温度上昇が大きく なり寿命が短縮される。

一方, 容量值は電源部の大きさなどの笑用的問題のため, あま り大きな值を選択できない、そこでコンデンサは耐リップルグレ 一ドの高いものを選択したり, 温度上昇と寿命の関係についても 


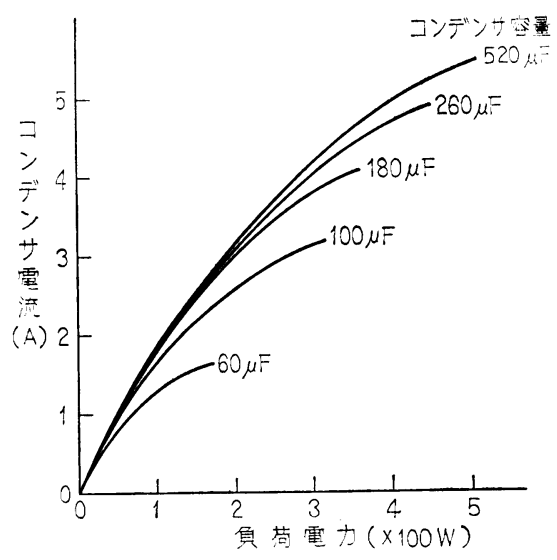

图 12 负荷電力とコンデンサ電流

十分知る必要が生ずる、コンデンサの周囲温度と寿命については メーカー，品種により種々㐫るが，代表的なものについて温度上 昇と寿命の関係をプロットすると図13のようになる．推定寿 命はアレニウスの法則を適用して得た7).

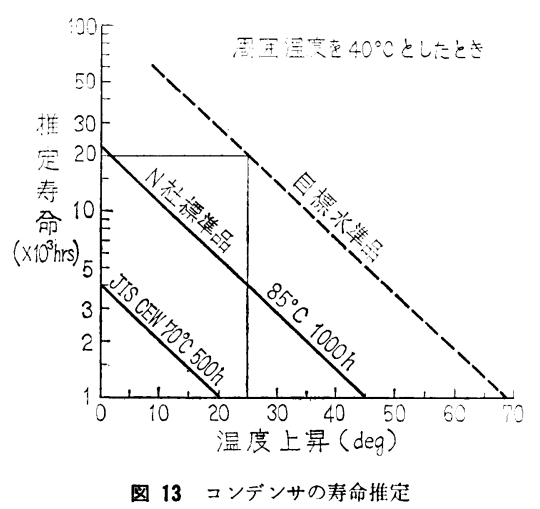

この図は電源部の設置䨌田気温度最大值を $40^{\circ} \mathrm{C}$ と考光, その 值に電源部の発熱による温度上昇を加算して、 コンデンサの周囲 温度として寿命を推定したものである. ランプの寿命を 6,000 㬨 間に設定し，回路部の寿命をその 3 倍以上の 20,000 時間と考学る と, $85^{\circ} \mathrm{C}, 1,000$ 時間程度の市販品ではほとんど温度上昇が許容 できない：図 14 にこのクラスのコンデンサのケース表面温度上 昇を測定した例を示す.

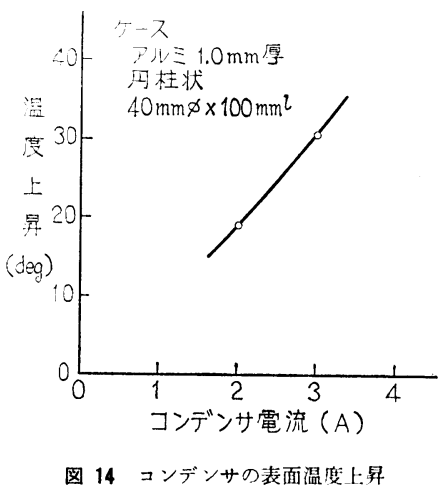

測定は回路部をアルミ製の金属ケース内に実装し、コンデンサ のケース表面に熱電対を設置して行なった. この例では $3 \mathrm{~A} の コ$ ンデンサ電流值において約 $30 \mathrm{deg}$ の温度上昇があることになる。 な打この温度上昇值は，コンデンサの ESR によるオーミックス な損失のほか，ダイオードなどの発熱などの周辺からの熱の影響
も含めて考兄ている．当然のことながら温度上昇值は回路外装ヶ 一スや内部の部品設置構造などの実装状態によって変化する。

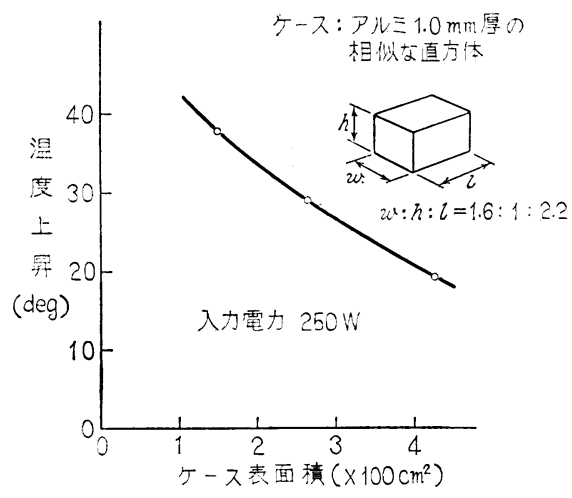

图 15 コンデンサ第囲合温度上:界

図 15 は直方体のアルミ製外装ダース内に同路部を导装して， 间ケースの大きさを変えた場合に，コンデンサの温度上昇がどう なるかを調べたものである。この例では外装ヶースの表面積を $400 \mathrm{~cm}^{2}$ 以上にすれば，温度上昇值を $20 \mathrm{deg}$ 程度まで下げ得るこ とがわかるが，いずれにしても目標の回路寿命20,000時間を得る ためには，高リップル電流用の耐熱コンデンサ老必要とする。筆 者らは目䧣の寿命水準尼 $65^{\circ} \mathrm{C}, 20,000$ 時間とした。

すなわち四13の破線で示される水準のもので，こ机を用いて電 源部の武作を行なったときに，コンデンサの表面温度上昇傎が 25 deg を越えないことを一つの目安とした。このため陚作にあたっ ては外装ケースの寸法, 形状, 材質, 内部構造, 特にダイオード などの発熱源との分離に注意を払った。

\section{5. 特 性}

試作したランプの電気 㧍よび光学的特性データを，表 2 拉よ び表 3 にまとめる. $100 \mathrm{~V}-250 \mathrm{~W}$ クラスでは, ランプ効㸉で $33 \mathrm{~lm} / \mathrm{W}$, 回路部を含めた総合効垶で $32 \mathrm{~lm} / \mathrm{W}$ を得, ほぼ設計

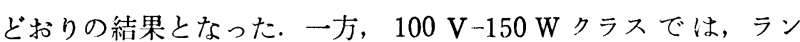
プ効率が $23 \mathrm{~lm} / \mathrm{W}$ とやや低くなったが，これは発光管電压比が 小さいためと思われる．発光管電压比を 0.7 以上にすればも5少 し改善されよう。

表 2 ランプ 部 特 性

\begin{tabular}{|c|c|c|c|c|c|c|c|c|}
\hline 电力クラス & 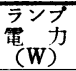 & $\begin{array}{l}\text { 発光管 } \\
\text { 男) } \\
\text { (W) }\end{array}$ & $\begin{array}{l}\text { 発光管 } \\
\text { 管力比 }\end{array}$ & $\begin{array}{l}\text { 発光管 } \\
\text { 電 } \\
\text { (V) }\end{array}$ & $\begin{array}{c}\text { 竞ち消完 } \\
\text { (V) } \\
\text { (V) }\end{array}$ & $\begin{array}{l}\text { 全光束 } \\
(\mathrm{lm})\end{array}$ & $\begin{array}{c}\text { ラソフ } \\
\text { 効/率 } \\
(\mathrm{lm} / \mathrm{W})\end{array}$ & $\begin{array}{l}\text { 総合効率 } \\
(1 \mathrm{~m} / \mathrm{W})\end{array}$ \\
\hline $170 \mathrm{~W}$ & 162 & 107 & 0.66 & 82 & 84 & 3,700 & 22.8 & 21.9 \\
\hline $250 \mathrm{~W}$ & 233 & 170 & 0.73 & 85 & 86 & 7,700 & 33.0 & 31.7 \\
\hline
\end{tabular}

表 3 回路 部 特性

\begin{tabular}{|c|c|c|c|c|c|c|c|c|}
\hline カクラス & $\begin{array}{c}\text { 入滆力 } \\
(W)\end{array}$ & \begin{tabular}{|c} 
入滆電 \\
(V)
\end{tabular} & $\begin{array}{c}\text { 入力電流 } \\
\text { (A) }\end{array}$ & $\begin{array}{l}\text { ランプ電 } \\
\text { 力 }(W)\end{array}$ & $\begin{array}{c}C_{m} \text { 容 } \\
(\mu \mathrm{F})\end{array}$ & $\begin{array}{c}C_{1} \text { 容 } \\
(\mu \mathrm{F})\end{array}$ & 一次力菨 & 回路効率 \\
\hline $170 \mathrm{~W}$ & 169 & 100 & 2.5 & 162 & 330 & 1.0 & 0.68 & 0.96 \\
\hline $250 \mathrm{~W}$ & 243 & 100 & 3.5 & 233 & 330 & 1.0 & 0.69 & 0.96 \\
\hline
\end{tabular}

各部電力の入力電圧に対する変動特性を図 16 に, 容量に対 する変動特性を図 17 におの抢の示すこれらより電圧変化に 対する影響はやや大きいが，容量変化に対する影響はきわめて 小さいことが確認された．試作ランプの低温始動性能については $-20^{\circ} \mathrm{C}$ においても問題ないものであった。

回路部は，ダイオードと電解コンデンサの損失のために 7 ～10 $\mathrm{W}$ の電力損が生じ変換効率は 0.96 程度となる. またコンデンサ 

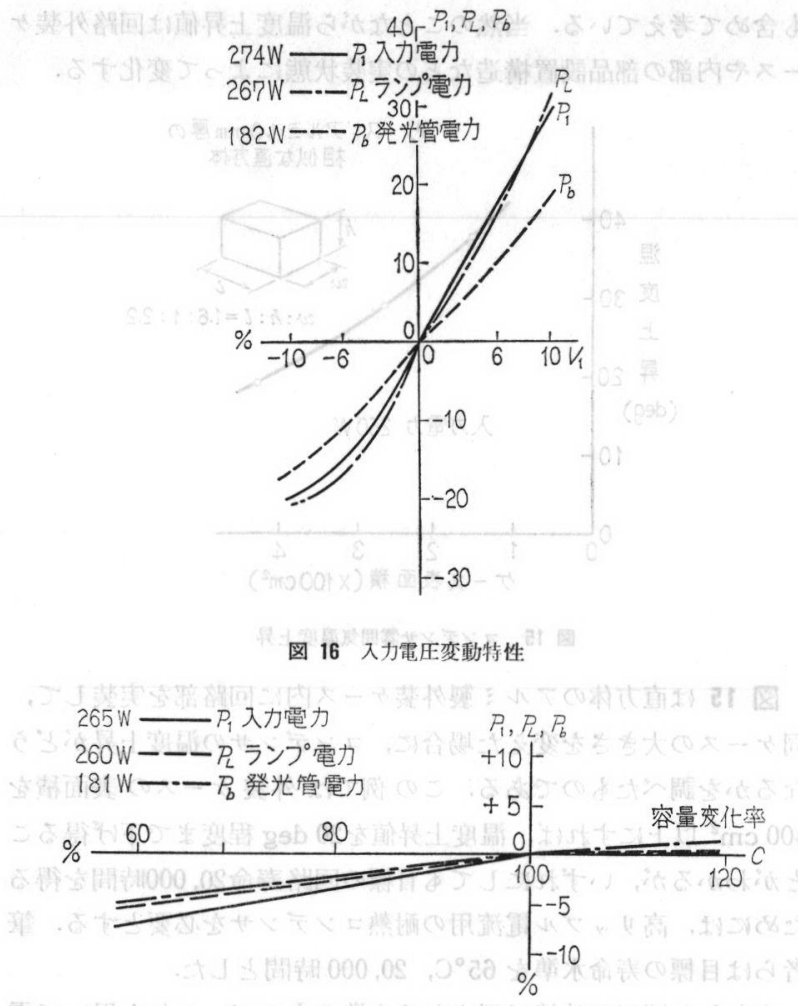

図17 容量值变動特性

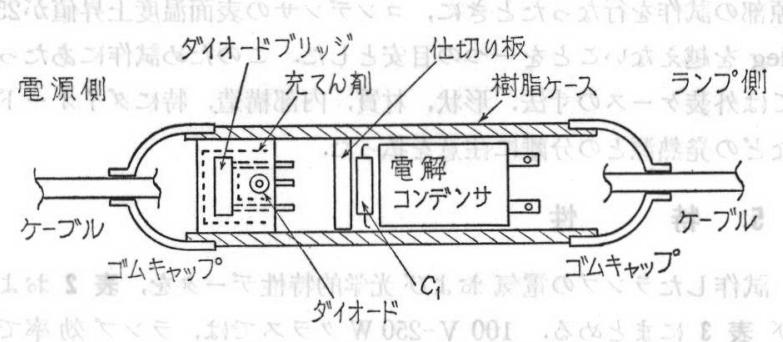

园 18 回路部の構造例 (回路別置方式)
の容量値が大きいので一次力率が0. 68〜0.69 となる.

回路常数数よび使用部品は両クラスとも同一とした.

回路部の外装ケースとして円柱状の樹脂ケースを用いた例を， その内部構造とともに図 18 に示す.ダイオード部を樹脂で充 てんした上，仕切り板により熱的にコンデンサを分離する.この 試作品の周囲温度上昇值は約 $26 \mathrm{deg}$ であった。

\section{6. ま と め}

直流点灯方式とすることにより, 発光管電圧比を 0.7 程度に選 ぶことが可能となり, 安定器内蔵形水銀ランプの効率を 2 倍程度 に向上させることがでさた．また，整流回路を工夫することによ って $100 \mathrm{~V}$ の電源電圧に括いても, 熱陰極発光管を用いることな く十分な始動性能を得るとともに, 従来の倍電圧整流点灯に起き る電解コンデンサの発熱に基づく寿命短縮の問題も解決できる見 通しである.このような回路は比較的小型軽量であるので, 設置 場所としては別置方式，照明器具に内蔵する方式，ランプロ金部 に内蔵する方式などいろいろ考えられる。

参 考 文 献

（1）高須 啓次：GS-News 31-2（昭47）80

(2) Dobrusskin, A., Kühl, B.: Lichttechnik 15-11 (1963) 554

(3) Lake, W. H.: Light. Des. Appl. 5-10 (1975) 33

(4) 特公昭 54-3311

(5) JIS C 5140-1970

(6) JIS C5141-1982

(7) 矢口ほか：「コンデンサの性能と用い方」東京電機大学出 版局第 2 版（昭41）52 53

（受付1984年 2 月 6 日）

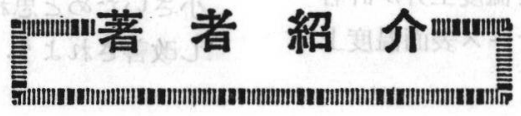

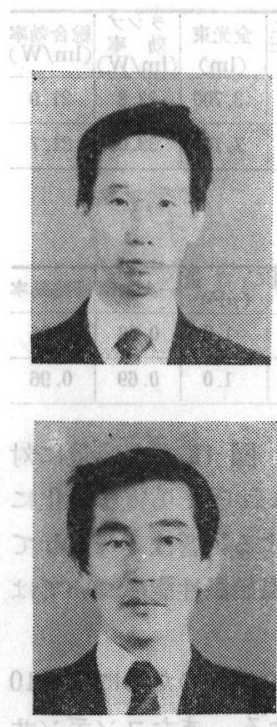

\section{越智雅文君 (正会員)}

昭和 20 年 10 月 25 日生まれ. 昭和 43 年 3 月 名古屋工業大学電子工学科卒業. 昭和 44 年 4 月岩崎電気株式会社に入社, 以来開発部 にて, 主に放電灯点灯回路の開発に従事 し, 現在に至る.

\section{满木ざ教一君}

昭和 23 年 4 月 24 日生まれ. 昭和 46 年 3 月 相模工業大学電気工学科卒業. 昭和 46 年 4 月岩崎電気株式会社に入社, 以来開発部に て, 主に放電灯の開発に従事し, 現在に至 る.
下垣 光太郎君 (専門会員)

昭和59年 2 月号参照.

水野 銛章君 (正会員)

昭和 57 年 4 月号参照.

矢橋 清二君 (正 会 員)

昭和 57 年 10 月号参照.

石川 太郎君（専門会員）

昭和 57 年 4 月号参照. 